\title{
HEART RATE AND OTHER RISK FACTORS IN OUTPATIENTS WITH STABLE CORONARY ARTERY DISEASE IN LATVIA
}

\author{
Inga Balode*, Sanda Jēgere ${ }^{\star *}$, Iveta Mintāle**, Inga Narbute**, Gustavs Latkovskis*****, \\ and Andrejs Ërglis ${ }^{* *, * * *}$ \\ * Rīga Stradiṇš University, Dzirciema iela 16, Rīga, LV-1017, LATVIA, \\ e-mail: inga.balode@Iv.netgrs.com \\ ** Latvian Centre of Cardiology, Pauls Stradiṇš Clinical University Hospital, Pilsoṇu 13, Rīga, LV-1002, LATVIA \\ ${ }^{* * *}$ Faculty of Medicine, University of Latvia, Šarlotes 1a, Rĩga, LV-1001, LATVIA
}

Contributed by Andrejs Ërglis

The aim of the study was to characterise coronary artery disease (CAD) outpatients in Latvia by risk factors (RF) including heart rate (HR), physical examination data, clinical data and treatment. Twelve practitioners had each examined and questioned 6 to 12 patients with established CAD $(n=120)$. The most frequent cardiovascular (CV) RF and co-morbidity were dyslipidemia (94.2\%) and hypertension (78.3\%), respectively. Prevalence of increased resting HR ( $\geq 70 \mathrm{bpm})$ was $35.9 \%$ and $33.6 \%$, when measured by pulse palpation and electrocardiography, respectively. Regarding other RFs, prevalence of treated but insufficiently controlled blood pressure 140/90 $\mathrm{mmHg}$, total cholesterol $1>5 \mathrm{mmol} / \mathrm{l}$ and triglycerides $>1.7 \mathrm{mmol} / \mathrm{l}$ was $25.8 \%, 30.1 \%$ and $33.3 \%$, respectively. Aspirin, statins and angiotensin-converting enzyme inhibitors or angiotensin-receptor blockers were used in $96.7 \%, 94.2 \%$ and $85.0 \%$ of cases, respectively. Beta blockers were used in $81.7 \%$ of cases. Average daily doses of most frequently used B blockers (metoprolol and bisoprolol) were $32 \%$ and $53 \%$ from target doses, respectively. In three cases B blockers were combined with ivabradin. Our results suggest that practitioners follow guidelines and consider CV prevention by treating CAD patients. Our data identified, however, unused potential for better control of increased HR by higher doses and combinations of HR-reducing agents.

Key words: resting heart rate, risk factors, coronary artery disease, outpatient.

\section{INTRODUCTION}

Coronary artery disease (CAD) is a highly prevalent cardiovascular (CV) pathology. CAD is the main cause of mortality worldwide and is a major burden on public health (Leal et al., 2006). It has been established that CAD will remain the leading cause of death for coming decades (Mathers and Loncar, 2006). CV mortality in Latvia is higher than in the European Union on average (Anonīms, 2010). In the future, number of CAD patients may be increasing due to aging of the population and improved prognosis of coronary patients (Tunstall-Pedoe et al., 1999). Recent advances in management of CAD have resulted in more effective treatment for acute coronary syndrome, revascularization and improved prevention. Nevertheless, CAD remains a major public health concern and improvement of outcomes of the disease continues to be a challenge.

Clinical characteristics of patients with CAD as well as understanding of risk factors and treatment have markedly changed over the years. Recently, strong evidence has been found that supports the concept of resting heart rate (HR) being an important prognostic risk factor (Diaz et al., 2005;
Fox et al., 2008a; Bohm et al., 2010). The prospective BEAUTIFUL study confirmed the prognostic value of increased resting $\mathrm{HR}$ in stable CAD patients with left ventricular dysfunction and showed that $\mathrm{HR} \geq 70$ beats per minute (bpm) is associated with significantly increased CV risk in CAD patients (Fox et al., 2008a). Results of another prospective study SHIFT showed that high HR is a risk factor in heart failure and an important target for treatment (Bohm et al., 2010).

Based on a large body of evidence, high resting HR has been included as an independent CV risk factor in the latest European and Latvian guidelines on $\mathrm{CV}$ disease prevention (Ërglis u.c., 2007; Graham et al., 2007). Recent European guidelines on CV disease prevention recommend measurement of HR as an integral part of the assessment for total CV risk (Graham et al., 2007).

Taking into account the evolving concept of high resting $\mathrm{HR}$ as a correctable risk factor of CAD, there is growing demand for information on the resting HR level in clinical practice, particularly in outpatients. 
The aim of the study was to characterise outpatients with stable CAD in Latvia by survey and analysis of data on demographics, prevalence of risk factors (including increased HR), lifestyle, medical history, physical examination data, clinical data and treatment.

\section{MATERIALS AND METHODS}

We surveyed 120 outpatients with treated stable CAD. Ten cardiologists and two general practitioners working in different regions of Latvia participated in the study. Each of the practitioners had examined 6 to $12 \mathrm{CAD}$ patients. CAD was confirmed by history of at least one of the following inclusion criteria: documented myocardial infarction (more than three months ago), coronary stenosis more than $50 \%$ (confirmed by coronary angiography), chest pain in combination with myocardial ischemia (confirmed by stress ECG, stress echocardiography or myocardial imaging), coronary revascularisation (coronary artery bypass graft $(\mathrm{CABG})$ and percutaneous coronary intervention (PCI)) more than three months ago. Exclusion criteria were hospitalisation due to $\mathrm{CV}$ disease within the last three months, planned revascularisation and limited cooperation of the patient. Data were collected during one visit to each practitioner during the period from November 2009 to March 2010.

The case report form contained the following parts: demographic information (age, gender, employment status, education level); risk factors and lifestyle (family history of premature $\mathrm{CAD}$, treated hypertension, diabetes, dyslipidemia, peripheral arterial disease, smoking status, alcohol intake $(1$ drink $=$ standard measure of spirits $/ 1$ glass of wine $/ 1$ bottle of beer), stimulant drinks (coffee and tea), and physical activity); medical history; physical examination; current symptoms (angina and congestive heart failure (CHF) symptoms); most recent measurements (if available) of glucose level, total cholesterol, high density lipoprotein cholesterol (HDL), low density lipoprotein cholesterol (LDL), triglycerides, serum creatinine level, and left ventricular ejection fraction (LVEF), a non invasive test for myocardial ischemia; and current treatment.

Resting HR was estimated by two methods: pulse palpation and electrocardiography (ECG). Pulse palpation was performed after sitting for at least $5 \mathrm{~min}$ in a quiet room with comfortable temperature. After this period, HR was measured for 30 seconds. Two measurements were taken, and the second was recorded. For ECG the most recent 12-lead ECG within six months was analysed. High HR was defined as $\geq 70$ (bpm), in accordance with recent evidence (Fox et al., 2008a). A low HDL level was defined as $<1.2 \mathrm{mmol} / 1$ for women and $<1 \mathrm{mmol} / \mathrm{l}$ for men, in accordance with Latvian guidelines on CV prevention (Ērglis u.c., 2007). Waist circumference $\geq 80 \mathrm{~cm}$ for women and $\geq 94 \mathrm{~cm}$ for men was defined as increased, according to criteria of metabolic syndrome (Alberti et al., 2005). Target doses for the $\beta$ blockers metoprolol and bisoprolol were defined as $200 \mathrm{mg}$ and 10 mg daily, respectively, in accordance with an expert con- sensus document on 3 -adrenergic receptor blockers (LopezSendon et al., 2004).

Data were processed using methods of descriptive statistics. The determination of correlations and significant differences was conducted using the Statistical Package for the Social Sciences (SPSS), version 15.0. $P$ values $<0.05$ were considered as statistically significant.

\section{RESULTS}

Heart rate. Resting HR ranges determined by pulse palpation and ECG were 52 to $101 \mathrm{bpm}$ and 46 to $105 \mathrm{bpm}$, respectively. Mean values of resting HR by pulse palpation $(67.7 \pm 9.61 \mathrm{bpm})$ and ECG $(66.9 \pm 10.7 \mathrm{bpm})$ did not significantly differ $(P>0.05)$. We also did not find statistically significant differences in mean HR between women and men: by pulse palpation $69.6 \pm 11.9 \mathrm{bpm}$ and $67.0 \pm 8.5$ bpm, respectively $(P>0.05)$; by ECG $68.7 \pm 12.6 \mathrm{bpm}$ and $66.2 \pm 9.9 \mathrm{bpm}$, respectively $(P>0.05)$.

Regarding different levels of HR (<60, 60-64, 65-69, $70-74,75-79,80-84,>85$ ), a level from 60 to 64 bpm was observed in $39(32.5 \%)$ and $22(22.7 \%)$ cases by palpation and ECG, respectively (Table 1$)$. Increased resting HR $(\geq 70$ bpm) occurred in $43(35.9 \%)$ cases when measured by palpation and in $40(33.6 \%)$ cases when measured by ECG. A total of 45 patients $(37.5 \%)$ had increased resting HR, estimated by palpation and by ECG.

The resting HR level did not significantly differ in relation to family history of premature CAD, treated hypertension, diabetes, dyslipidemia, smoking and physical activity. We did not find a significant correlation begtween resting HR and number of smoked cigarettes per day, usage of stimulant drinks and age.

Similarly, current symptoms (presence of angina, number of angina attacks per week, symptoms of CHF) were not associated with HR. Patients with increased HR $(\geq 70 \mathrm{bpm})$ did not have more frequent angina attacks than those with $\mathrm{HR}<$ 70 bpm.

Table 1

RESTING HEART RATE LEVELS MEASURED BY PULSE PALPATION AND ECG

\begin{tabular}{|c|c|c|c|c|}
\hline \multirow{2}{*}{$\begin{array}{c}\text { Resting heart rate levels } \\
\text { (beats per minute) }\end{array}$} & \multicolumn{2}{|c|}{ By pulse palpation } & \multicolumn{2}{|c|}{ By ECG } \\
\hline & $\mathrm{n}$ & $\%$ & $\mathrm{n}$ & $\%$ \\
\hline$<60$ & 16 & 13.3 & 26 & 21.8 \\
\hline $60-64$ & 39 & 32.5 & 27 & 22.7 \\
\hline $65-69$ & 22 & 18.3 & 26 & 21.8 \\
\hline $70-74$ & 17 & 14.2 & 11 & 9.2 \\
\hline $75-79$ & 11 & 9.2 & 17 & 14.3 \\
\hline $80-84$ & 8 & 6.7 & 5 & 4.2 \\
\hline$\geq 85$ & 7 & 5.8 & 7 & 5.9 \\
\hline Total & 120 & 100 & 119 & 100 \\
\hline
\end{tabular}

ECG, electrocardiography 
Regarding physical examination data and most recent measurements, HR showed low but significant correlation with diastolic blood pressure (by pulse palpation: $\mathrm{r}=0.270,(P<$ $0.05)$; by ECG: $\mathrm{r}=0.260,(P<0.05)$ and negatively with LVEF (by pulse palpation: $\mathrm{r}=-0.254,(P<0.05)$; by ECG: $\mathrm{r}=-0.261,(P<0.05)$. No other significant HR correlations with the investigated parameters were found.

Other risk factors and lifestyle. Age of patients was within the range from 45.7 to 80.1 years. Mean age in studied population was $64.2 \pm 7.9$ years. Breakdown of patients in different age groups is shown in Table 2. The proportion of females was $33(27.5 \%)$. Half of the patients had retired (Table 3 ).

Frequencies of positive family history of premature CAD, treated hypertension, diabetes, dyslipidemia, peripheral artery disease, smoking and physical activity are shown in Table 4 .

Women more frequently had positive history of premature CAD $(42.4 \%$ vs $17.2 \%,(P<0.01)$ and more favourable smoking status $(P=0.001)$. None of the examined women were current smokers, in contrast to $25.3 \%$ of men. Mean number of cigarettes smoked per day was commonly (in 11 $(50 \%)$ cases) was 10 . Former smokers had stopped smoking 1 to 42 years previously to examination. Mean time period after smoking discontinuation was $11.2 \pm 13.5$ years. Most patients $(\mathrm{n}=56,46.7 \%)$ had only light physical activity (Table 4) and there were no significant differences in physical activity according to gender.

Alcohol intake was positive in 81 cases $(67.5 \%)$, of which three $(3.4 \%)$ men consumed 20 to 40 drinks per week (Table 5). There were significant differences in alcohol intake according to gender $(P=0.005)$. Noteworthy, in 117

Table 2

AGE GROUPS OF PATIENTS

\begin{tabular}{lrrr}
\hline Age (years) & $\mathrm{n}$ & $(\%)$ \\
\hline $40-49$ & 4 & 3.3 \\
$50-59$ & 34 & 28.3 \\
$60-69$ & & 46 & 38.3 \\
$\geq 70$ & Total & 36 & 30.0 \\
& & 120 & 100
\end{tabular}

Table 3

EMPLOYMENT STATUS OF PATIENTS

\begin{tabular}{|c|c|c|c|c|c|c|}
\hline \multirow{3}{*}{$\begin{array}{c}\text { Employment } \\
\text { status }\end{array}$} & \multicolumn{4}{|c|}{ Gender } & \multirow{2}{*}{\multicolumn{2}{|c|}{ Total }} \\
\hline & \multicolumn{2}{|c|}{ Women } & \multicolumn{2}{|c|}{ Men } & & \\
\hline & $\mathrm{n}$ & $\%$ & $\mathrm{n}$ & $\%$ & $\mathrm{n}$ & $\%$ \\
\hline Employed full-time & 4 & 12.1 & 29 & 33.3 & 33 & 27.5 \\
\hline Employed part-time & 1 & 3.0 & 8 & 9.2 & 9 & 7.5 \\
\hline Unable to work & 2 & 6.1 & 4 & 4.6 & 6 & 5.0 \\
\hline Unemployed & 2 & 6.1 & 7 & 8.0 & 9 & 7.5 \\
\hline Retired & 24 & 72.7 & 36 & 41.4 & 60 & 50.0 \\
\hline Other & 0 & 0 & 3 & 3.4 & 3 & 2.5 \\
\hline Total & 33 & 100 & 87 & 100 & 120 & 100 \\
\hline
\end{tabular}

(97.5\%) cases, patients consumed stimulant drinks (Table $5)$. Most commonly ( $\mathrm{n}=47,39.2 \%)$, patients had two cups of stimulant drinks per day.

Body mass index (BMI) was within the range from 20 to 45 $\mathrm{kg} / \mathrm{m}^{2}$, with mean value of $29.3 \pm 4.4 \mathrm{~kg} / \mathrm{m}^{2}$; there was no significant difference between genders. Distribution of patients in different BMI groups is shown in Table 6. The mean BMI was higher in men $(P<0.05)$.

Waist circumference was significantly higher in men $(P=$ $0.001)$. Increased waist circumference ( $\geq 80 \mathrm{~cm}$ for women and $\geq 94 \mathrm{~cm}$ for men) was observed in $106(88.3 \%)$ cases: in $30(90.0 \%)$ women and $76(87.4 \%)$ men.

Systolic blood pressure was within the range from 100 to $190 \mathrm{~mm} \mathrm{Hg}$ with a mean value $138.3 \pm 14.1 \mathrm{~mm} \mathrm{Hg}$. Diastolic blood pressure was within the range from 60 to 110

T able 4

FREQUENCY OF FAMILY HISTORY OF PREMATURE CAD, TREATED HYPERTENSION, DIABETES, DYSLIPIDEMIA, PERIPFERAL ARTERY DISEASE, SMOKING AND PHYSICAL ACTIVITY ACCORDING TO GENDER

\begin{tabular}{|c|c|c|c|c|c|c|c|}
\hline \multirow{3}{*}{\multicolumn{2}{|c|}{ Risk factors }} & \multicolumn{4}{|c|}{ Gender } & \multirow{2}{*}{\multicolumn{2}{|c|}{ Total }} \\
\hline & & \multicolumn{2}{|c|}{ women } & \multicolumn{2}{|c|}{ men } & & \\
\hline & & $\mathrm{n}$ & $\%$ & $\mathrm{n}$ & $\%$ & $\mathrm{n}$ & $\%$ \\
\hline \multirow{3}{*}{$\begin{array}{l}\text { Family history } \\
\text { of CAD }\end{array}$} & Yes & 14 & 42.4 & 15 & 17.2 & 29 & 24.2 \\
\hline & No & 19 & 57.6 & 72 & 82.8 & 91 & 75.8 \\
\hline & Total & 33 & 100 & 87 & 100 & 120 & 100 \\
\hline \multirow{3}{*}{$\begin{array}{l}\text { Treated hyper- } \\
\text { tension }\end{array}$} & Yes & 28 & 84.8 & 66 & 75.9 & 94 & 78.3 \\
\hline & No & 5 & 15.2 & 21 & 24.1 & 26 & 21.7 \\
\hline & Total & 33 & 100 & 87 & 100 & 120 & 100 \\
\hline \multirow[t]{3}{*}{ Diabetes } & Yes & 6 & 18.2 & 20 & 23.0 & 26 & 21.7 \\
\hline & No & 27 & 81.8 & 67 & 77.0 & 94 & 78.3 \\
\hline & Total & 33 & 100 & 87 & 100 & 120 & 100 \\
\hline \multirow[t]{3}{*}{ Dyslipidemia } & Yes & 31 & 93.9 & 82 & 94.3 & 113 & 94.2 \\
\hline & No & 2 & 6.1 & 5 & 5.7 & 7 & 5.8 \\
\hline & Total & 33 & 100 & 87 & 100 & 120 & 100 \\
\hline \multirow{3}{*}{$\begin{array}{l}\text { Peripheral ar- } \\
\text { tery disease }\end{array}$} & Yes & 2 & 6.1 & 6 & 6.9 & 8 & 6.7 \\
\hline & No & 31 & 93.9 & 81 & 93.1 & 112 & 93.3 \\
\hline & Total & 33 & 100 & 87 & 100 & 120 & 100 \\
\hline \multirow[t]{4}{*}{ Smoking status } & Current & 0 & 0 & 22 & 25.3 & 22 & 18.3 \\
\hline & Former & 4 & 12.1 & 45 & 51.7 & 49 & 40.8 \\
\hline & Never & 29 & 87.9 & 20 & 23.0 & 49 & 40.8 \\
\hline & Total & 33 & 100 & 87 & 100 & 120 & 100 \\
\hline \multirow[t]{4}{*}{$\begin{array}{l}\text { Physical activ- } \\
\text { ity weekly }\end{array}$} & $\begin{array}{c}\text { No physical } \\
\text { activity } \\
\text { weekly }\end{array}$ & 3 & 9.1 & 5 & 5.7 & 8 & 6.7 \\
\hline & $\begin{array}{l}\text { Only light } \\
\text { activity }\end{array}$ & 19 & 57.6 & 37 & 42.5 & 56 & 46.7 \\
\hline & $\begin{array}{l}\text { Vigorous ac- } \\
\text { tivity at least } \\
20 \text { ' once or } \\
\text { twice }\end{array}$ & 6 & 18.2 & 17 & 19.5 & 23 & 19.2 \\
\hline & $\begin{array}{l}\text { Vigorous ac- } \\
\text { tivity at least } \\
20^{\prime} \geq 3 \text { times }\end{array}$ & 5 & 15.2 & 28 & 32.2 & 33 & 27.5 \\
\hline
\end{tabular}

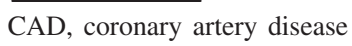


ALCOHOL AND STIMULANT DRINK CONSUMPTION ACCORDING TO GENDER

\begin{tabular}{|c|c|c|c|c|c|c|c|}
\hline \multirow{2}{*}{\multicolumn{2}{|c|}{$\begin{array}{c}\text { Alcohol / } \\
\text { stimulant drinks }\end{array}$}} & \multicolumn{4}{|c|}{ Gender } & \multirow{2}{*}{\multicolumn{2}{|c|}{ Total }} \\
\hline & & \multicolumn{2}{|c|}{ women } & \multicolumn{2}{|c|}{ men } & & \\
\hline & & $\mathrm{n}$ & $\%$ & $\mathrm{n}$ & $\%$ & $\mathrm{n}$ & $\%$ \\
\hline \multirow{5}{*}{$\begin{array}{l}\text { Alcohol intake } \\
\text { (number of } \\
\text { drinks* per } \\
\text { week) }\end{array}$} & 0 & 18 & 54.5 & 21 & 24.1 & 39 & 32.5 \\
\hline & $>0$ and $<20$ & 15 & 45.5 & 63 & 72.4 & 78 & 65.0 \\
\hline & $20-40$ & 0 & 0 & 3 & 3.4 & 3 & 2.5 \\
\hline & $>40$ & 0 & 0 & 0 & 0 & 0 & 0 \\
\hline & Total & 33 & 100 & 87 & 100 & 120 & 100 \\
\hline \multirow{4}{*}{$\begin{array}{l}\text { Stimulant } \\
\text { drink con- } \\
\text { sumption }\end{array}$} & Coffee & 21 & 63.6 & 49 & 56.3 & 70 & 58.3 \\
\hline & Tee & 12 & 36.4 & 35 & 40.2 & 47 & 39.2 \\
\hline & $\begin{array}{l}\text { Neither } \\
\text { coffee/tee }\end{array}$ & 0 & 0 & 3 & 3.4 & 3 & 2.5 \\
\hline & Total & 33 & 100 & 87 & 100 & 120 & 100 \\
\hline
\end{tabular}

$* 1$ drink $=$ standard measures of spirits $/ 1$ glass of wine $/ 1$ bottle of beer

Table 6

BODY MASS INDEX GROUPS ACCORDING TO GENDER

\begin{tabular}{c|c|c|c|c|c|c}
\hline \multirow{2}{*}{$\begin{array}{c}\text { Body mass index } \\
\left(\mathrm{kg} / \mathrm{m}^{2}\right)\end{array}$} & \multicolumn{5}{|c|}{ Gender } & \multicolumn{3}{c}{ Total } \\
\cline { 2 - 6 } & \multicolumn{2}{|c|}{ women } & \multicolumn{2}{c}{ men } & \multicolumn{2}{c}{} \\
\cline { 2 - 6 } & $\mathrm{n}$ & $\%$ & $\mathrm{n}$ & $\%$ & $\mathrm{n}$ & $\%$ \\
\hline $18.5-24.9$ & 8 & 24.2 & 9 & 10.3 & 17 & 14.2 \\
$25.0-29.9$ & 13 & 39.4 & 43 & 49.4 & 56 & 46.7 \\
$30.0-34.9$ & 9 & 27.3 & 27 & 31.0 & 36 & 30.0 \\
$35.0-39.9$ & 1 & 3.0 & 8 & 9.2 & 9 & 7.5 \\
$40.0-45.0$ & 2 & 6.1 & 0 & 0 & 2 & 1.7 \\
Total & 33 & 100 & 87 & 100 & 120 & 100
\end{tabular}

$\mathrm{mm} \mathrm{Hg}$ with a mean value $82.9 \pm 8.6 \mathrm{~mm} \mathrm{Hg}$. We did not find a significant difference in systolic and diastolic blood pressure between men and women. In $31(25.8 \%)$ cases, including $8(24.2 \%)$ women and 23 (26.4\%) men, blood pressure was $140 / 90 \mathrm{~mm} \mathrm{Hg}$ or above.

Medical history. The medical history of patients is shown in Table 7. Mean time after diagnosis of CAD was $5.6 \pm 5.3$ years. Mean time after PCI (in patients with history of PCI) was $2.7 \pm 3.0$ years. Men significantly more commonly had history of CABG than women: $28.7 \%$ vs $9.1 \%(P<0.05)$.

Current symptoms. Angina or equivalent symptoms were positive in 57 (47.5\%) patients. Distribution of patients according to the Canadian Cardiovascular Society (CCS) classification of angina was as follows: class I: $16(28.1 \%)$, class II: 36 (63.2\%), class III: 5 (8.8\%).

Symptoms of CHF were positive in 70 (58.3\%) of patients. Severity of symptoms according to the New York Heart Association (NYHA) classification of CHF was as follows: one (1.4\%) patient had class II, 64 (91.4\%) had class III and $5(7.1 \%)$ patients had class IV.

Most recent measurements. Glucose, total cholesterol, HDL, LDL and triglyceride levels are shown in Table 8.
MEDICAL HISTORY OF PATIENTS

\begin{tabular}{|c|c|c|c|c|c|c|c|}
\hline \multirow{3}{*}{\multicolumn{2}{|c|}{ Diagnosis }} & \multicolumn{4}{|c|}{ Gender } & \multirow{2}{*}{\multicolumn{2}{|c|}{ Total }} \\
\hline & & \multicolumn{2}{|c|}{ women } & \multicolumn{2}{|c|}{ men } & & \\
\hline & & $\mathrm{n}$ & $\%$ & $\mathrm{n}$ & $\%$ & $\mathrm{n}$ & $\%$ \\
\hline \multirow{3}{*}{$\begin{array}{l}\text { Myocardial } \\
\text { infarction }\end{array}$} & Yes & 18.0 & 54.5 & 58.0 & 66.7 & 76 & 63.3 \\
\hline & No & 15.0 & 45.5 & 29 & 33.3 & 44 & 36.7 \\
\hline & Total & 33 & 100 & 87 & 100 & 120 & 100 \\
\hline \multirow{3}{*}{$\begin{array}{l}\text { Percutaneous } \\
\text { coronary } \\
\text { intervention }\end{array}$} & Yes & 26 & 78.8 & 62 & 71.3 & 88 & 73.3 \\
\hline & No & 7 & 21.2 & 25 & 28.7 & 32 & 26.7 \\
\hline & Total & 33 & 100 & 87 & 100 & 120 & 100 \\
\hline \multirow{3}{*}{$\begin{array}{l}\text { Coronary artery } \\
\text { bypass graft }\end{array}$} & Yes & 3 & 9.1 & 25 & 28.7 & 28 & 23.3 \\
\hline & No & 30 & 90.9 & 62 & 71.3 & 92 & 76.7 \\
\hline & Total & 33 & 100 & 87 & 100 & 120 & 100 \\
\hline \multirow{3}{*}{$\begin{array}{l}\text { Aortic abdomi- } \\
\text { nal aneurysm }\end{array}$} & Yes & 0 & 0 & 1 & 1.1 & 1 & 0.8 \\
\hline & No & 33 & 100.0 & 86 & 98.9 & 119 & 99.2 \\
\hline & Total & 33 & 100 & 87 & 100 & 120 & 100 \\
\hline \multirow[t]{3}{*}{ Carotid disease } & Yes & 3 & 9.1 & 6 & 6.9 & 9 & 7.5 \\
\hline & No & 30 & 90.9 & 81 & 93.1 & 111 & 92.5 \\
\hline & Total & 33 & 100 & 87 & 100 & 120 & 100 \\
\hline \multirow[t]{3}{*}{ Stroke } & Yes & 2 & 6.0 & 1 & 1.1 & 3 & 2.5 \\
\hline & No & 31 & 94.0 & 86 & 98.9 & 117 & 97.5 \\
\hline & Total & 33 & 100 & 87 & 100 & 120 & 100 \\
\hline \multirow{3}{*}{$\begin{array}{l}\text { Transient } \\
\text { ischemic attack }\end{array}$} & Yes & 2 & 6.1 & 4 & 4.6 & 6 & 5.0 \\
\hline & No & 31 & 93.9 & 83 & 95.4 & 114 & 95.0 \\
\hline & Total & 33 & 100 & 87 & 100 & 120 & 100 \\
\hline \multirow{3}{*}{$\begin{array}{l}\text { Hospitalsation } \\
\text { for chronic heart } \\
\text { failure }\end{array}$} & Yes & 1 & 3.0 & 2 & 2.2 & 3 & 2.5 \\
\hline & No & 32 & 97.0 & 85 & 97.8 & 117 & 97.5 \\
\hline & Total & 33 & 100 & 87 & 100 & 120 & 100 \\
\hline \multirow{3}{*}{$\begin{array}{l}\text { Atrial fibrillation } \\
\text { or flutter }\end{array}$} & Yes & 4 & 12.1 & 7 & 8.0 & 11 & 9.2 \\
\hline & No & 29 & 87.9 & 80 & 92.0 & 109 & 90.8 \\
\hline & Total & 33 & 100 & 87 & 100 & 120 & 100 \\
\hline \multirow{3}{*}{$\begin{array}{l}\text { Asthma or } \\
\text { chronic obstruc- } \\
\text { tive pulmonary } \\
\text { disease }\end{array}$} & Yes & 2 & 6.1 & 4 & 4.6 & 6 & 5.0 \\
\hline & No & 31 & 93.9 & 83 & 95.4 & 114 & 95.0 \\
\hline & Total & 33 & 100 & 87 & 100 & 120 & 100 \\
\hline
\end{tabular}

Serum creatinine levels, which were available in 93 cases, ranged from 2.6 to $157.0 \mu \mathrm{mol} / \mathrm{l}$ with a mean value of 87.9 $\pm 23.2 \mu \mathrm{mol} / \mathrm{l}$. The mean creatinine level differed significantly between gender: $75.9 \pm 14.9 \mu \mathrm{mol} / \mathrm{l}$ and $92.6 \pm 24.3$ $\mu \mathrm{mol} / \mathrm{l}$ in women and men, respectively $(P=0.001)$.

LVEF, estimated in 96 cases, was within the range from 31 to $79 \%$ with a mean value of $57.1 \pm 8.7 \%$.

A non invasive test for myocardial ischemia had been performed in 107 (89.2\%) cases. Evidence of myocardial ischemia in a non invasive test was observed in $8(6.7 \%)$ cases.

Current treatment. Treatment of patients with different classes of drugs is shown in Figure 1.

Preventive treatment. As an antitrombotic agent, aspirin was used in 116 (96.7\%) cases and thienopyridine for 16 $(13.6 \%)$ patients. Regarding lipid lowering agents, 113 
MOST RECENT MEASUREMENTS

\begin{tabular}{|c|c|c|c|c|c|c|}
\hline Measurements & $\begin{array}{c}\% \text { of patients from total } \\
\text { population with avail- } \\
\text { able measurement }\end{array}$ & Range & Mean value \pm SD & Different levels & $\mathrm{n}$ & $\%$ \\
\hline \multirow[t]{4}{*}{ Glucose level (mmol/1 } & \multirow[t]{4}{*}{88.3} & \multirow[t]{4}{*}{$4.4-10.2$} & \multirow[t]{4}{*}{$6.1 \pm 1.3$} & $<5.6$ & 49 & 46.2 \\
\hline & & & & $\geq 5.6$ to $<7.0$ & 39 & 36.8 \\
\hline & & & & $\geq 7$ & 18 & 17.0 \\
\hline & & & & Total & 106 & 100 \\
\hline \multirow[t]{5}{*}{ Total cholesterol (mmol/l) } & \multirow[t]{5}{*}{94.2} & \multirow[t]{5}{*}{$2.8-9.8$} & \multirow{5}{*}{$4.7 \pm 1.3$} & $<3.5$ & 16 & 14.2 \\
\hline & & & & $\geq 3.5$ to $<5.0$ & 63 & 55.8 \\
\hline & & & & $\geq 5.0$ to 6.0 & 22 & 19.5 \\
\hline & & & & $\geq 6.0$ & 12 & 10.6 \\
\hline & & & & Total & 113 & 100 \\
\hline \multirow{2}{*}{$\begin{array}{l}\text { High density lipoprotein } \\
\text { cholesterol (mmol/l) }\end{array}$} & \multirow[t]{2}{*}{85.0} & \multirow[t]{2}{*}{ 0.6-7.1 } & \multirow{2}{*}{$1.4 \pm 0.7$} & Low* & 31 & 28.8 \\
\hline & & & & Total & 104 & 100 \\
\hline \multirow{5}{*}{$\begin{array}{l}\text { Low density lipoprotein } \\
\text { cholesterol }(\mathrm{mmol} / \mathrm{l})\end{array}$} & \multirow[t]{5}{*}{89.2} & \multirow[t]{5}{*}{$0-7.0$} & \multirow[t]{5}{*}{$2.7 \pm 1.2$} & $<1.8$ & 25 & 23.4 \\
\hline & & & & $\geq 1.8$ to $<2.6$ & 33 & 30.8 \\
\hline & & & & $\geq 2.6$ to $<3.5$ & 29 & 27.0 \\
\hline & & & & $\geq 3.5$ & 20 & 18.7 \\
\hline & & & & Total & 107 & 100 \\
\hline \multirow[t]{3}{*}{ Tryglycerides (mmol/l) } & \multirow[t]{3}{*}{90.0} & \multirow[t]{3}{*}{$0.3-6.8$} & \multirow[t]{3}{*}{$1.7 \pm 1.1$} & $>1.7$ & 36 & 33.3 \\
\hline & & & & Other & 72 & 66.7 \\
\hline & & & & Total & 108 & 100 \\
\hline
\end{tabular}

SD - standard deviation

* $<1.2 \mathrm{mmol} / \mathrm{l}$ for women and $\mathrm{mmol} / \mathrm{l}$ for men

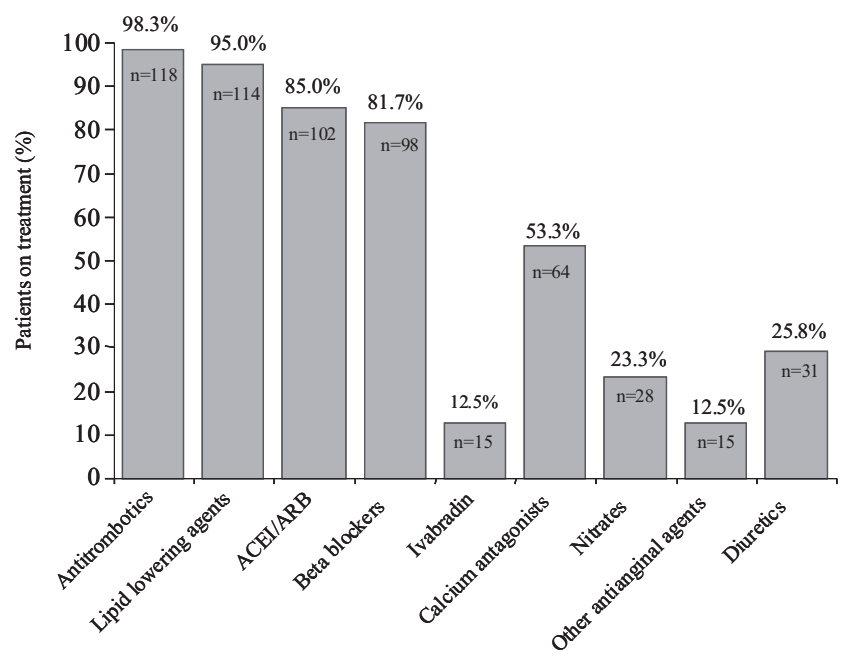

Fig. 1. Treatment of patients with different classes of drugs. ACEI, angiotensin-converting enzyme inhibitors; ARB, angiotensin-receptor blockers.

(94.2\%) patients received statins. Among renin-angiotensin system antagonists, $85(70.8 \%)$ patients received angiotensin-converting enzyme inhibitor (ACEI) and 17 (14.2\%) were given angiotensin-receptor blocker (ARB). Both agents were never used concomitantly.

HR reducing agents. The beta blocker metoprolol (average daily dose (ADD) $64.4 \pm 24.9 \mathrm{mg}$ ) was administered in 47
(39.2\%) cases, bisoprolol (ADD: $5.3 \pm 2.3 \mathrm{mg}$ ) in 37 $(30.8 \%)$ patients, nebivolol (ADD: $4.8 \pm 0.8 \mathrm{mg}$ ) in 10 $(8.3 \%)$ patients, and carvedilol in $4(3.3 \%)$ cases. Twenty three $(19.2 \%)$ patients receiving $\beta$ blockers had symptoms of $B$ blockers contraindications or intolerance. Most commonly fatigue $(n=6,6.1 \%)$ and bradicardia $(n=6,6.1 \%)$ was observed. Fifteen (12.5\%) patients received ivabradin (ADD: $7.0 \pm 3.8 \mathrm{mg}$ ), which is another HR-reducing agent. Among the patients receiving ivabradin, 3 (20\%) concomitantly received $\beta$ blocker.

\section{HR-reducing agents in the group of patients with in-} creased resting $H R \geq 70 \mathrm{bpm}$

The most commonly used $\beta$ blockers in the group of patients with $\mathrm{HR} \geq 70 \mathrm{bpm}(\mathrm{n}=45)$ were metoprolol $(\mathrm{n}=20$, $44.4 \%)$ and bisoprolol $(\mathrm{n}=11,24.4 \%)$ with ADD $68.8 \pm$ $29.7 \mathrm{mg}$ and $5.8 \pm 2.8 \mathrm{mg}$, respectively. Six (13.3\%) patients in this group received ivabradin (ADD: $8.3 \pm 4.1 \mathrm{mg}$ ) and two of them received $B$ blocker in combination with ivabradin. Eight (17.6\%) patients with increased resting HR ( $\geq 70 \mathrm{bpm}$ ) did not receive a $B$ blocker and in $5(11.1 \%)$ cases neither a $\beta$ blocker nor ivabradin was used.

Other CV agents. All patients receiving $\mathrm{Ca}$ antagonists used dihydropyridine type $\mathrm{Ca}$ antagonists. Thirty two $(56.1 \%)$ and $24(42.1 \%)$ patients from the group with angina or equivalent symptoms were receiving $\mathrm{Ca}$ antagonists and long-acting nitrates, respectively. Six (31.6\%) and 12 
(63.2\%) patients from those having angina or equivalent symptoms concomitantly with $\mathrm{HR} \geq 70 \mathrm{bpm}$ were receiving $\mathrm{Ca}$ antagonists and long-acting nitrates, respectively. Fifteen $(12.5 \%)$ patients received other antianginal agents and $12(10.0 \%)$ received treatment with other antihypertensive medicine.

In three $(2.5 \%)$, five $(4.2 \%)$ and four $(3.3 \%)$ cases patients received digoxin, amiodaron and other antiarrythmics, respectively.

\section{DISCUSSION}

The characteristics of our sample group were similar to those found in other studies with CAD patients: similar mean age of patients, proportion of males and females, body mass index and percentage of smokers (Anonymous, 2008; Boden et al., 2007). Also, the list of co-morbidities, with hypertension as the most frequent, is in line with findings of other studies with CAD patients (Anonymous, 2008; Boden et al., 2007). The most frequent CV risk factor is history of dyslipidemia (94.2\%). The proportion of patients with increased HR ( $\geq 70$ bpm), a recently established CV risk factor, is similar to the proportion of patients with treated but still not adequately controlled other risk factors: $35.9 \%$ of patients with resting HR by pulse palpation $\geq 70 \mathrm{bpm}$; $25.8 \%$ patients with blood pressure above 140/90 mm Hg; $30.1 \%$ patients with total cholesterol1 > $5 \mathrm{mmol} / \mathrm{l} ; 45.8 \%$ patients with LDL $>2.6 \mathrm{mmol} / \mathrm{l} ; 28.8 \%$ patients with HDL $<1.2 \mathrm{mmol} / \mathrm{l}$ for women and $<1 \mathrm{mmol} / \mathrm{l}$ for men; $33.3 \%$ patients with triglyceride level $>1.7 \mathrm{mmol} / \mathrm{l}$.

The studied population can be compared with Euro Heart Survey (EHS) and REALITY Latvia data, although in those studies only patients with stable angina were surveyed. The EHS study reviewed information from 156 cardiology clinics in 34 countries. In that study 3031 patients were included on the basis of a new clinical diagnosis of stable angina by a cardiologist (Daly et al., 2006). Comparison of our data with results of REALITY Latvia results are particularly interesting, as this study reflects the situation in Latvia with stable angina management four years before our study. REALITY Latvia, which examined information from about 300 stable angina outpatients treated by cardiologists, highlighted increased HR and its management (Balode et al., 2010).

REALITY Latvia indicated good trends in treatment of stable angina with wider usage of agents that improve CAD prognosis and are recommended by guidelines (Fox, 2006), compared with mean estimates from Europe. In REALITY, a larger proportion of patients were treated with aspirin (91\% vs $78 \%$ ), other antiplatelets (20\% vs 9\%), statins ( $83 \%$ vs $48 \%$ ), beta blockers ( $91 \%$ vs $67 \%$ ), ACEI ( $82 \%$ vs $40 \%$ ) than in EHS (Balode et al., 2010; Daly et al., 2005). In our study, the proportion of patients using agents that improve prognosis (Fox, 2006) was also high. Usage of aspirin and statins in our study was even more frequent than in REALITY Latvia: $96.7 \%$ vs $91 \%$ and $94.2 \%$ vs $83 \%$, respec- tively (Balode et al., 2010). This indicates a favourable trend towards following guidelines and considering $\mathrm{CV}$ prevention treatment of CAD patients. In our study Beta blockers were used less than in the REALITY Latvia study ( $81.7 \%$ vs $91 \%)$, but this does not mean weaker control of increased HR. The resting HR level in our study was even lower than in the REALITY Latvia study: $67.7 \pm 9.6 \mathrm{bpm}$ by pulse palpation and $66.9 \pm 10.7 \mathrm{bpm}$ by ECG in our study vs $70.3 \pm 11.3 \mathrm{bpm}$ in the REALITY Latvia study. Also, the proportion of patients with increased HR $(\geq 70$ bpm) in our study was lower than in the REALITY Latvia study: $35.9 \%$ by pulse palpation and $33.6 \%$ by ECG in our study vs $45 \%$ in the REALITY Latvia study. This cannot be explained by higher doses of $\beta$ blockers as ADD for the most frequently used $B$ blockers were similar: for metoprolol $64.4 \pm 24.9$ and $69.7 \pm 30.1$; for bisoprolol $5.3 \pm 2.3$ $\mathrm{mg}$ and $5.3 \pm 2.0$, in our sample and the REALITY Latvia study, respectively. Doses of the used $\beta$ blockers corresponded to $32 \%$ and $53 \%$ from the target dose for metoprolol and bisoprolol, respectively (Lopez-Sendon et al., 2004). This is not surprising, as $\beta$ blockers have poor long-term compliance and under-dosing of $\beta$ blockers is typical in the community. In practice, patients are using $50 \%$ or less of the dosages used in clinical trials (Gislason, 2006). The lower proportion of patients using $B$ blockers in our sample group, in comparison with the REALITY Latvia study can be explained by the new HR reducing agent ivabradin, which is mainly used instead of $\beta$ blockers in cases where patients have intolerance or contraindications. Ivabradin was not available at the time when the REALITY Latvia study was performed; but in our study $12.5 \%$ of patients were treated with ivabradin. Ivabradin is a heart rate lowering agent that does not influence other cardiac functions. Ivabradin has antianginal and antiishemic efficacy (Anonymous, 2011). There is also evidence of the ability of ivabradin to reduce risk of events (Fox et al., 2008b; 2009; Swedberg et al., 2010). It should be noted that ADD of ivabradin in our study was $7.0 \pm 3.8 \mathrm{mg}$, which is less than $50 \%$ of the full dose ( $15 \mathrm{mg}$ daily), thus the potential for full effect was underused (Anonymous, 2011).

In our sample group, the proportion of CAD patients with increased HR ( $\geq 70 \mathrm{bpm})$ was lower than in the EHS study (Daly et al., 2008) (35.9\% vs 53\%). This seems encouraging and shows a trend towards better control of HR and therefore better management of risk factors in CAD patients.

In our study, patients were mainly treated by cardiologists. In real life, stable CAD patients are more frequently treated by general practitioners. Acceptation of increased HR as an independent $\mathrm{CV}$ risk factor and important target for treatment can be significantly powerless among general practitioners in comparison with cardiologists, and therefore, HR control in patients treated by general practitioners is with high probability weaker.

High mortality from CV diseases in Latvia (Anonīms, 2010) indicates a need for practitioners to use all possibilities to control $\mathrm{CV}$ risk factors, especially when treating 
CAD patients. HR is one of the most frequently assessed clinical parameters, which can be easily monitered even by patients. Taking into account the association of increased HR with CV events (Fox et al., 2008a) in CAD patients HR should be well controlled.

Our data indicate unused potential for better control of this risk factor. Doses of HR-reducing agents in the group of patients with increased resting HR ( $\geq 70 \mathrm{bpm})$ are similar with those in total population, and the proportion of patients not receiving $\beta$ blockers in the group with $\mathrm{HR} \geq 70 \mathrm{bpm}$ is very close to that in the total population $(17.6 \%$ and $18.3 \%$, respectively). Also, more than $10 \%$ of patients with increased resting HR $(\geq 70 \mathrm{bpm})$ did not receive any HR-reducing agent. Commonly, ivabradin was not combined with a $\beta$ blocker. Only three patients (20\% from all using ivabradin) concomitantly received a $\beta$ blocker. Insufficient reduction of HR was an indication for combination of $\beta$ blocker and ivabradin. However, only 2 (4.4\%) of all patients with increased resting HR $(\geq 70 \mathrm{bpm})$ received this combination. An increase of the $\beta$ blocker dose is not always possible, even if patient has high HR, and in those cases combination with ivabradin can be applicable for better HR control.

Limitations for interpretation of the results should be acknowledged, as the number of patients involved was relatively small and the data are collected only in one visit. Selection bias may also have taken place. For better understanding of how management of risk factors (including increased $\mathrm{HR}$ ) in stable CAD patients is changing, longer studies with a follow-up period are needed.

In conclusion, the results of study indicate that characteristics of outpatients with stable CAD in our sample were typical for CAD in other studies. The most frequent CV risk factor was dyslipidemia and the most frequent co-morbidity in CAD patients was hypertension. Prevalence of increased HR ( $\geq 70 \mathrm{bpm})$, a recently established CV risk factor, was similar to other treated but not adequately controlled risk factors.

Compared to previous studies performed in Latvia and internationally, we observed a favourable trend of the following guidelines in terms of $\mathrm{CV}$ protection for stable $\mathrm{CAD}$ outpatients. However, our data indicated an unused potential for better control of increased HR by higher doses and combinations of HR-reducing agents.

\section{ACKNOWLEDGMENTS}

This survey was supported by Servier Latvia.

Study Coordinator Andrejs Ërglis, investigators Gustavs Latkovskis, Iveta Mintāle and authors are grateful to all investigators: Santa Ābele, Anita Baika, Veronika Ečina, Silvija Hansone, Inga Jasinkeviča, Ināra Laizāne, Irīna Mihailova, Ausma Kondratoviča, Natalja Pontaga, Nadežda Rožkova.

\section{REFERENCES}

Alberti, K.G., Zimmet, P., Shaw, J. (2005) The metabolic syndrome - a new worldwide definition. Lancet, 366, 1059-1062.

Anonīms (2010). Latvijas veselības statistikas gadagrāmata par 2009. gadu [Yearbook of Latvian Health Statistics for 2009]. Rìga: VSMTVA (Veselības statistikas un medicīnas tehnoloǵiju valsts aǵentūra), 2010 (in Latvian).

Anonymous (2011). Procoralan SPC (Summary of Product Characteristics) http://www.ema.europa.eu/docs/en_GB/document_library/EPAR_Product_ Information/human/000597/WC500043590.pdf (last viewed 13.06.2011).

Anonymous (2008). The BEAUTIFUL Study Group. The BEAUTIFUL study: Randomized trial of ivabradine in patients with stable coronary artery disease and left ventricular systolic dysfunction — baseline characteristics of the study population. Cardiology, 110, 271-282.

Balode, I., Jēgere, S., Mintāle, I., Narbute, I., Zakke, I., Latkovskis, G., Ërglis, A. (2010). Current state of angina treatment in the outpatient population and heart rate monitoring survey in Latvia (REALITY Latvia). Proc. Latv. Acad. Sci., Section B, 64(5/6), 194-201.

Boden, W.E., O’Rouke, R., Teo, K.T., Hartigan, P.M., Maron, D.J., Kostuk, W.I., Knudston, M., Dada, M., Casperson, P., Harris, C.L., Chaitman, B.R., Shaw, L., Gosselin, G., Navaz, S., Title, L.M. Gau, G., Blaustein, A.S., Booth, D.C., Bates, E.R., Spertus, J.A., Berman, D.S., Mancini, J., Weintraub, W.S. for the COURAGE Trial Research Group. (2007). Optimal Medical Therapy with or without PCI for Stable Coronary Disease. $N$ Engl. J. Med., 356. www.nejm.org.

Bohm, M., Swedberg, K., Komajda, M., Borer, J., Ford, I., Dubost-Brama, A., Lerebous, G., Tavazzi, L., on behalf of the SHIFT investigators (2010) .Heart rate as a risk factor in chronic heart failure (SHIFT): The association between heart rate and outcomes in a randomised placebo-controlled trial. Lancet, 376, 886-894.

Daly, C.A., Clemens, F., Lopez Sendon, J. L., Tavazzi, L., Boersma, E., Danchin, N., Delahaye, F., Gitt, A., Julian, D., Mulcahy, D., Ruzyllo, W., Thygesen, K., Verheugt, F., Fox K.M. (2005). The initial management of stable angina in Europe, from the Euro Heart Survey: A description of pharmacological management and revascularization strategies initiated with the first month of presentation to a cardiologist in the Euro Heart Survey of Stable Angina. Eur. Heart J., 26, 1011-1022.

Daly, C.A., De Stavola, B., Lopez-Sendon, J. L., Tavazzi, L, Boersma, E., Clemens, F., Danchin, N., Delahaye, F., Gitt, A., Julian, D., Mulcahy, D., Ruzyllo, W., Thygesen, K., Verheugt, F., Fox K.M. (2006). Predicting prognosis in stable angina - results from the Euro Heart Survey of stable angina: Prospective observational study. BMJ, 332, 262-267.

Daly, C., Tavazzi, L., Fox, K., Euro Heart Survey of Angina Investigators (2008) Inadequate control of heart rate in patients with stable angina: Results from the European Heart Survey. Eur. Heart J., 29 (Abstract Supplement), 204.

Diaz, A., Bourassa, M. G., Guertin, M. C., Tardif, J. C. (2005). Long term prognostic value of resting heart rate in patients with suspected or proven coronary artery disease. Eur. Heart J., 26(10), 967-974.

Ērglis, A., Kalvelis, A., Lejnieks, A., Dzērve, V., Latkovskis, G., Mintāle, I., Zakke, I., Rasa, I. (2007). Kardiovaskulāro slimību (KVS) profilakses vadlīnijas [Guidelines on cardiovascular disease prevention]. Rīga. 45. lpp. (in Latvian).

Fox, K., Garcia, M.A.A., Ardissino, D., Buszman, P., Camici, P.G., Crea, F., Daly, C., Backer, G., Hjemdahl, P., Lopes-Sendon, J., Marco, J., Morais, J., Pepper, J., Sechtem, U., Simoons, M., Thygesen, K. (2006). Guidelines on the management of stable angina pectoris. The Task Force on the Managment of Stable Angina Pectoris of the European Society of Cardiology. Eur. Heart J., 27, 341-1381.

Fox, K., Ford, I., Steg, P. G., Tendera, M., Robertson, M., Ferrari, R., BEAUTIFUL investigators (2008a) Heart rate as a prognostic risk factor in patients with coronary artery disease and left-ventricular systolic dysfunction (BEAUTIFUL): A subgroup analysis of a randomised controlled trial. Lancet, 372, 817-821. 
Fox, K., Ford, I., Steg, P. G., Tendera, M., Ferrari, R., BEAUTIFUL investigators (2008b) Ivabradine for patients with stable coronary artery disease and left-ventricular systolic dysfunction (BEAUTIFUL): A randomised, double-blind, placebo-controlled trial. Lancet, 372, 807-816.

Fox, K., Ford, I., Steg, P. G., Tendera, M., Robertson, M., Ferrari, R., BEAUTIFUL investigators (2009) Relationship between ivabradine treatment and cardiovascular outcomes in patients with stable coronary artery disease and left ventricular systolic function with limiting angina: A subgroup analysis of the randomized, controlled BEAUTIFUL trial. Eur. Heart J., 30, 2337-2345

Gislason, G.H., Rasmussen, J.N., Abildstrom, S.Z., Gadsboll, N., Buch, P., Friberg, J., Rasmussen, S., Kober, L., Stender, S., Madsen, M., and Torp-Pederden, C. (2006). Long term compliance with beta-blockers, angiotensin-converting inhibitors, and statins after acute myocardial infarction. Eur. Heart J., 27, 1153-1158.

Graham, I., Atar, D., Borch-Johnsen, K., Boysen, G., Burell, G., Cifkova, R., Dallongeville, J., De Backer, G., Ebrahim, S., Gjelsvik, B., HerrmannLingen, C., Hoes, A., Humphries, S., Knapton, M., Perk, J., Priori, S.G., Pyorala, K., Reiner, Z., Ruilope, L., Sans-Menendez, S., Reimer, V.S.O., Weissberg, P., Wood, D., Yarnell, Y., Zamorano, J. L. (2007). European

Received 29 August 2011 guidelines on cardiovascular disease prevention in clinical practice: Executive summary. Eur. Heart J., 28, 2375-2414.

Leal, J., Luengo-Fernindez, R., Gray, A., Petersen, S., Rayner, M. (2006). Economic burden of cardiovascular diseases in the enlarged European Union. Eur. Heart J., 27(13), 1610-1619.

Lopez-Sendon, J., Swedberg, K., McMurray J., Tamargo, J., Maggioni, A.P., Dargie, H.,Tendera, M., Waagstein, F., Kjekshus, J., Lechat, P., TorpPedersen, C. (2004). Expert consensus document on ā-adrenergic receptor blockers. The Task Force on Beta-Blockers of the European Society of Cardiology. Eur. Heart J., 25, 1341-1362.

Mathers, C.D., Loncar, D. (2006). Projections of global mortality and buren of disease from 2002 to 2030. PLoS Med., Nov, 3, e442.

Tunstall-Pedoe, H., Kuulasmaa, K., Mahonen, M., Tolonen, H., Ruokokoski, E., Amouyel, P., for the WHO MONICA (monitoring trends and determinants in cardiovascular disease) Project (1999) Contribution of trends in survival and coronary-event rates to changes in coronary heart disease mortality: 10-year results from 37 WHO MONICA Project populations. Lancet, 353, 1547-1557.

Swedberg, K., Komajda, M., Bohm, M., Borer, J., Ford, I., Dubost-Brama, A., Lerebous, G., Tavazzi, L., on behalf of the SHIFT investigators (2010) Ivabradine and outcomes in chronic heart failure (SHIFT): A randomised placebo-controlled study. Lancet, 376, 875-885.

\section{SIRDSDARBĪBAS FREKVENCE UN CITI RISKA FAKTORI AMBULATORI ĀRSTĒTIEM PACIENTIEM AR STABILU KORONĀRO SIRDS SLIMĪBU LATVIJĀ}

Novērojuma mērḳis bija raksturot ambulatori ārstētus pacientus ar stabilu koronāro sirds slimību (KSS) Latvijā - riska faktoru (RF), tajā skaitā palielinātas sirdsdarbības frekvences (SF) sastopamību, fizikālās un klīniskās izmeklēšanas rezultātus un ārstēšanu. Vienas vizītes ietvaros tika apsekoti un iztaujāti 120 ambulatori ārstēti pacienti ar stabilu KSS. Divpadsmit praktizējoši ārsti katrs ievāca datus par 6-12 pacientiem un aizpildīja gadījuma ziņojuma veidlapas. Biežāk sastopamais kardiovaskulārais (KV) RF bija dislipidēmija (94,2\%), biežākā blakus saslimšana - arteriālā hipertensija (78,3\%). Palielināta SF ( $\geq 70 \mathrm{x} / \mathrm{min}$ ) bija 35,9\% gadījumu, nosakot ar pulsa palpāciju un 33,6\%, nosakot ar elektrokardiogrāfijas metodi. Citu ārstētu, bet nekontrolētu RF sastopamība bija sekojoša: arteriālais asinsspiediens $140 / 90$ mm $\mathrm{Hg}$ bija 25,8\% pacientu, kopējais holesterīns $5 \mathrm{mmol} / \mathrm{l}$ - 30,1\%, triglicerīdi 1,7 mmol/1 - 33,3\% pacientu. Aspirīnu saṇēma 96,7\% pacientu, statīnus - 94,2\%, bet angiotenzīnu konvertējošā enzīma inhibitorus vai angiotenzīna receptoru blokatorus - 85,0\% pacientu. Beta blokatori tika lietoti $81,7 \%$ gadījumu. Biežāk lietoto beta blokatoru metoprolola un bisoprolola vidējās devas bija attiecīgi $32 \%$ un $53 \%$ no mērḳa devām. Trijos gadījumos beta blokatori tika kombinēti ar ivabradīnu. Novērojuma rezultāti ḷauj secināt: praktizējošie ārsti, ārstējot KSS pacientus, seko vadlīnijām un cenšas uzlabot pacientu prognozi. Tomēr ir vēl papildus iespējas labāk kontrolēt palielinātu SF, lietojot lielākas SF samazinošo līdzekḷu devas un tos kombinējot. 